Chubokha N. On the Issue of Interests in the Civil Law. The article examines the concept of interest as a civil law category and its correlation with objective law. The author interprets interest as conscious ambitions and needs of a person, his/her volitional actions aimed at achieving a desired legitimate result, acquisition and exercising subjective civil rights. The author argues that there is a need to distinguish between interest and objective civil law and determines the mechanisms of their implementation in civil law. The study refutes the need to apply a legitimate interest, which is traditionally interpreted as a natural human interest since it is a pre-legal category based on social, moral, and ethical norms. Natural interest is a kind of interest that is not defined by objective law and is a simple factual permission for a person to act at his/her own discretion for the realization of specific social weals. As an extra-legal category, it is a prerequisite for the subjective right of a person and is defined as permissible in the future social behavior of a person, which corresponds to the spirit and essence of law or that does not contradict them and is carried out on the principle - «allowed is what is not prohibited by law». The content of this interest involves two main human ambitions: the actual - to enjoy some social benefits within the general permits, and the second (moral and ethical one) - to seek protection if necessary in case of violation or impossibility to realize one's ambitions. The interests of society and the private interests of the individual person are the objective basis for the coexistence and interaction of public and private law. It is very important that both the private interests of each and the interests of society be recognized and protected. Only with the harmonious combination and coordination of the interests of the whole society in legal regulation is possible to get the consistent and dynamic development of society, including in the field of personal non-property and property civil relations.

Key words: private interest, public interest, objective law, subjective law.

УДК 349.6(477+061.1€C):658.7]:502.171:32

DOI https://doi.org/10.32782/2409-4544/2020-1/13

Л. Шевчук

\title{
Екологічна політика держави у сфері публічних закупівель: підходи СС та законодавство України
}

Досліджено теоретико-правові основи екологічної політики України в сфері державних закупівель в умовах європейської інтеграції держави. Проаналізовано екологічні стандарти ЄС i ï закріплення в національному законодавстві. Відзначено, що введення Законом № 114-IX норм екологічного характеру є результатом послідовного наближення законодавства України до acquis ЄC в сфері закупівель відповідно до Угоди про асоціацію. Обгрунтовано висновок про те, що посилення екологічної складової в національному законодавстві характеризує сучасну політику України, орієнтовану на стандарти СС у сфері закупівель відповідно до Директиви 2014/24/СС. Відзначено, що окремі норми екологічного характеру, передбачені зазначеною Директивою 2014/24/ЄС, на цей час не знайшли належного закріплення в національній нормативно-правовій базі в сфері закупівель. На основі аналізу новел законодавчого регулювання екологічних аспектів закупівельної діяльності, а також дослідження провідних вчених-екологів сформульовано авторське визначення поняття сучасної екологічної політики України в сфері державних закупівель. Сучасна екологічна політика України у сфері публічних закупівель $є$ комплексною системою дій, заходів та напрямів діяльності держави за участю суспільства, спрямованих на досягнення цілей сталого розвитку шляхом раціоналізації прямого й опосередкованого впливу людини та результатів ії діяльності на довкілля, зниження рівня забруднення навколишнього природного середовища, досягнення гармонійної взаємодії суспільства $\mathrm{i}$ природи, охорони й оздоровлення довкілля, збалансованого використання природних ресурсів, забезпечення екологічної безпеки (у тому числі безпеки життя і здоров’я людини) та підтримання екологічної рівноваги, стимулювання розвитку екоорієнтованих технологій тощо на усіх етапах здійснення закупівель товарів, робіт і послуг (з моменту планування закупівлі до укладення й 
виконання договору про закупівлю) для забезпечення потреб держави, територіальних громад та об'єднаних територіальних громад.

Ключові слова: екологічна політика, публічні закупівлі, здійснення публічних закупівель, закупівля товарів, робіт і послуг, Свропейський Союз.

Постановка наукової проблеми та їі значення. Збереження й охорона довкілля, екологічна безпека, раціональне та збалансоване природокористування, а також забезпечення сприятливого для життя і здоров'я людини навколишнього природного середовища тривалий час були й залишаються актуальними проблемами сьогодення, на вирішення яких спрямовані зусилля не тільки міжнародної спільноти загалом, але і кожної сучасної цивілізованої країни та об’єднань (союзів) держав зокрема.

Стратегія розв'язання означених екологічних проблем в Україні, з огляду на посилення існуючих глобалізаційних процесів та відповідно до обраного країною євроінтеграційного вектору їі розвитку, передбачає реалізацію пріоритетних національних програм у цій сфері з урахуванням прогресивного світового та європейського досвіду з цих питань та знаходить свій прояв у екологічній політиці держави. Остання, у свою чергу, характеризується упровадженням екосистемного підходу до регулювання ключових сфер державного та суспільного життя.

Основні засади (стратегія) державної екологічної політики України на період до 2030 року, затверджені Законом України від 28.02.2019 року № 2697-VIII (далі - Стратегія), як одне із завдань для досягнення цілі забезпечення сталого розвитку природно-ресурсного потенціалу України визначає запровадження в Україні системи зелених закупівель [1].

Частково наведене положення Стратегії реалізоване у спеціальному правовому акті - Законі України «Про публічні закупівлі» від 25.12.2015 р. № 922-VIII (далі - Закон № 922-VIII) [2] у редакції Закону України від 19.09.2019 р. № 114-IX (далі - Закон № 114-IX) [3], яким запроваджено окремі норми екологічного характеру при здійсненні закупівель товарів, робіт і послуг для забезпечення потреб держави, територіальних громад та об'єднаних територіальних громад.

Таке оновлення національного закупівельного законодавства $\epsilon$ не лише результатом поширення дії екологічної політики держави на сферу публічних закупівель, але й важливим кроком на шляху наближення України до стандартів Свропейського Союзу з цих питань.

Аналіз досліджень цієї проблеми. Реалізація екологічної політики держави в умовах євроінтеграції України, а також питання охорони довкілля, екологічної безпеки, раціонального природокористування, забезпечення сприятливого для життя і здоров'я людини навколишнього природного середовища $є$ предметом досліджень таких провідних учених, як В. І. Андрейцев, Г. В. Анісімова, Г. І. Балюк, А. П. Гетьман, О. С. Заржицький, I. І. Каракаш, В. В. Костицький, М. В. Краснова, Ю. А. Краснова, В. І. Лозо, Т. С. Харитонова, Ю. С. Шемшученко.

Разом з тим, проблематика сутності та змісту екологічної політики України у сфері публічних закупівель на нинішньому етапі розвитку держави залишається недостатньо опрацьованою.

Формулювання мети та завдань статті. Мета й завдання статті полягають у дослідженні теоретико-правових основ сучасної екологічної політики держави в національній закупівельній діяльності, а також окреслення перспективних напрямів іiі здійснення в умовах європейської інтеграції України.

Виклад основного матеріалу й обгрунтування отриманих результатів дослідження. Досить широка нормативно-правова база Європейського Союзу й України з питань навколишнього природного середовища, раціонального природокористування та охорони довкілля, прийнята упродовж кількох останніх десятиліть, однозначно засвідчує посилення уваги з боку національних та європейських інституцій до необхідності вирішення нагальних екологічних проблем, наявних у суспільстві.

При цьому, як слушно зауважує М. В. Краснова, еколого-правова наука не часто звертається до сфери дослідження поняття та правового забезпечення екологічної політики. Переважно такі питання розкриваються в навчально-методичній літературі в означенні екологічної функції держави при формуванні правового, організаційного, економічного та іншого механізму регулювання суспільних екологічних правовідносин $[4$, с. 10].

Такий стан речей значною мірою можна пояснити відсутністю визначення в Україні на рівні нормативно-правового акту самих термінів «екологічна політика», «державна екологічна політика», «екологічна політика держави» тощо. Навіть у Законі України «Про охорону навколишнього природного середовища» від 25.06. 1991 р. № 1264-XII зміст категорії «екологічна політика» окреслюється лише шляхом вказівки на iі цілі. Зокрема, у преамбулі цього акту зазначено, що «...Україна здійснює на своїй території екологічну політику, спрямовану на збереження безпечного 
для існування живої і неживої природи навколишнього середовища, захисту життя i здоров’я населення від негативного впливу, зумовленого забрудненням навколишнього природного середовища, досягнення гармонійної взаємодії суспільства і природи, охорону, раціональне використання і відтворення природних ресурсів» [5].

Немає визначення екологічної політики й у Законі України «Про засади внутрішньої i зовнішньої політики» від 01.07.2010 р. № 2411-VI. Водночас у ньому в ст. 9 регламентуються основні засади внутрішньої політики в екологічній сфері та сфері техногенної безпеки, у тому числі: 1) забезпечення конституційних прав громадян на безпечне довкілля, створення екологічно і техногенно безпечних умов життєдіяльності населення, посилення просвітницької діяльності з інформування населення про екологічні норми і стандарти; 2) збереження навколишнього природного середовища, вдосконалення національної екологічної політики, стимулювання розвитку екобезпечних технологій; 3) впровадження системи екологічно збалансованого використання природних ресурсів [6].

Відсутність легальної дефініції «екологічна політика» зумовлює багатоманітність та неоднаковість підходів до розуміння цієї категорії в наукових колах. Так, А. П. Гетьман визначає екологічну політику як систему державних заходів, що визначають вплив суспільства на довкілля, тактику й стратегію збалансованого розвитку [7, с. 45].

Досить широке розуміння екологічної політики пропонує М. В. Краснова, зазначаючи, що екологічну політику можна представити як систему дій та інституцій, яка забезпечує управління суспільними екологічними справами на різних рівнях 3 метою досягнення відповідної мети, здійснення контролю за діяльністю органів влади, заміни суб'єктів, які здійснюють владу в екологічних інтересах суспільства неефективно; це багатофункціональний соціальний феномен, який здатний забезпечувати залучення всіх членів суспільства до процесів вирішення сучасних екологічних проблем, пов'язаних зокрема з надмірним забрудненням довкілля внаслідок впливів різних видів господарювання [4, с. 10].

Таке формулювання учена визначає, грунтуючись на розумінні екологічної політики як сукупності громадсько-політичних, соціально-економічних, культурно-освітніх, організаційноправових заходів суб'єктів - індивідів, груп, партій, держави тощо, спрямованих на охорону навколишнього природного середовища, раціональне використання природних ресурсів i забезпечення екологічної безпеки [4, с. 10].

На думку О. С. Заржицького, екологічна політика являє собою комплекс засобів і заходів, спрямованих суспільством і державою на охорону та оздоровлення довкілля, ефективне поєднання природокористування і природоохорони та забезпечення нормальної життєдіяльності громадян [8, c. 9].

Таким чином, незалежно від акцентів, які наявні у наведених визначеннях й стосуються окреслення місця держави, суспільства i його інституцій, а також співвідношення їх ролі у регулюванні (здійсненні впливу) на довкілля задля вирішення екологічних проблем, названі автори однозначні у твердженнях стосовно того, що екологічна політика зорієнтована на охорону навколишнього природного середовища, ефективне природокористування, а також забезпечення екологічної безпеки та нормальної життєдіяльності людей.

3 цього приводу вкрай слушною є позиція А. П. Гетьмана, який підкреслює, що національна екологічна політика в сучасних умовах розглядається як інтегрований фактор соціально-економічного розвитку України, який сприяє забезпеченню переходу до сталого розвитку економіки та впровадження екологічно збалансованої системи природокористування [9, с. 56-57].

Це положення повною мірою стосується й нинішньої екологічної політики України у сфері публічних закупівель. Так, відповідно до Стратегії, у контексті запровадження в державі системи зелених закупівель задля досягнення цілі забезпечення сталого розвитку природно-ресурсного потенціалу України, Законом № 114-IX передбачені права замовників установлювати в тендерній документації вимоги до якісних (у тому числі екологічних) характеристик товарів, робіт і послуг, які закуповуються, а також вимагати від учасників підтвердження того, що пропоновані ними товари, послуги чи роботи за своїми екологічними чи іншими характеристиками відповідають вимогам, установленим у тендерній документації (п. 3 ч. 2 ст. 22, ч. 3 ст. 23, ч. 5 ст. 23) [3]. У разі встановлення екологічних чи інших характеристик товару, роботи чи послуги замовник повинен в тендерній документації зазначити, які маркування, протоколи випробувань або сертифікати можуть підтвердити відповідність предмета закупівлі таким характеристикам (ч. 5 ст. 23) [3].

Більше того, одним із можливих критеріїв оцінки тендерних пропозицій учасників п. 3 ч. 3 ст. 29 Закону № 114-IX визначена ціна/вартість життєвого циклу разом 3 іншими критеріями оцінки, 
зокрема, такими як застосування заходів охорони навколишнього середовища та/або соціального захисту, які пов'язані із предметом закупівлі [3].

Наведені норми екологічного характеру, запроваджені Законом № 114-IX, $є$ результатом послідовного наближення законодавства України до асquis ЄC у сфері закупівель, як це визначено в Главі 8 «Державні закупівлі» Угоди про асоціацію між Україною, з однієї сторони, та Європейським Союзом, Європейським співтовариством 3 атомної енергії і їхніми державами-членами, 3 іншої сторони (далі - Угода про асоціацію) [10], ратифікованій Законом України від 16.09.2014 р. № 1678VII [11]. Адаптація законодавства України acquis Європейського Союзу на виконання Угоди про асоціацію також визначена як складова мети Закону № 114-IX у його преамбулі [3].

Посилення екологічної складової у національному закупівельному законодавстві характеризує сучасну політику України, орієнтовану на відповідні стандарти ЄС у сфері закупівель. Останні, зокрема, містяться в Директиві 2014/24/СС Європейського парламенту і Ради ЄС від 26 лютого 2014 року про державні закупівлі та скасування Директиви 2004/18/ЕС (далі - Директива 2014/24/СС).

Низка норм Директиви 2014/24/СС - щодо можливості придбання замовниками робіт, товарів або послуг з конкретними екологічними характеристиками й посилання на конкретне маркування (екомаркування) (п. 75 преамбули); врахування екологічних аспектів контракту в складі критеріїв його присудження (ст. 67); врахування затрат протягом життєвого циклу продукту, послуг або робіт, у тому числі витрат, віднесених до зовнішніх екологічних чинників (ст. 68); екологічні міркування як особливі умови виконання контрактів (ст. 70) [12] - в цілому відображені у відповідних положеннях Закону № 114-IX.

Разом 3 тим, передбачені Директивою 2014/24/ЄС можливості замовників вимагати вжиття заходів екологічного менеджменту або схем, які застосовуватимуться при виконанні контракту (п. 88 преамбули) і їх право виключати з участі суб'єктів господарювання, які виявилися ненадійними, наприклад через порушення екологічних зобов’язань (п. 101 преамбули) [12] наразі не знайшли належного закріплення у національній закупівельній нормативно-правовій базі.

Однак аналіз сучасної екологічної політики держави у сфері публічних закупівель дозволяє прогнозувати, що у процесі подальшої адаптації законодавства України асquis Європейського Союзу на виконання Угоди про асоціацію, стратегічне завдання стосовно формування в нашій країні системи зелених закупівель буде виконуватися з урахуванням необхідності ширшого запровадження в національне правове поле та закупівельну практику європейських стандартів у цій сфері.

Висновки та перспективи подальшого дослідження. Цілком обгрунтовано можна констатувати, що в Україні екологічна політика держави у сфері публічних закупівель перебуває на етапі свого становлення й розвитку. Правова основа для неї закладена лише у зв'язку з прийняттям 28.02.2019 року Основних засад (стратегії) державної екологічної політики України на період до 2030 року та 19.09.2019 р. нової редакції Закону України «Про публічні закупівлі».

Попередні редакції Закону № 922-VIII, як і Основні засади (стратегія) державної екологічної політики України на період до 2020 року, затверджені Законом України від 21.12.2010 p. № 2818-VI [13], не містили норм екологічного характеру, які б регламентували закупівельну діяльність. Винятком є лише положення п. 3 ч. 2 ст. 22 Закону України «Про публічні закупівлі» в редакції від 25.12.2015 р., відповідно до якого технічні, якісні характеристики предмета закупівлі повинні передбачати необхідність застосування заходів із захисту довкілля [2].

Так само досі поза увагою українського законодавця залишалися світові та європейські підходи до екологізації публічних закупівель. Стимулом же до формування власної екологічної політики в Україні у закупівельній сфері стало підписання Угоди про асоціацію та впровадження основних екологічних стандартів Європейського Союзу в національне законодавство про закупівлі.

Аналіз новел законодавчого регулювання екологічних аспектів закупівельної діяльності, а також дослідження провідних учених-екологів дозволяють сформулювати теоретико-правове визначення сучасної екологічної політики України у сфері публічних закупівель, під якою слід розуміти комплексну систему дій, заходів та напрямів діяльності держави за участю суспільства, спрямованих на досягнення цілей сталого розвитку шляхом раціоналізації прямого й опосередкованого впливу людини та результатів іiі діяльності на довкілля, зниження рівня забруднення навколишнього природного середовища, досягнення гармонійної взаємодії суспільства i природи, охорони й оздоровлення довкілля, збалансованого використання природних ресурсів, забезпечення екологічної безпеки (у тому числі безпеки життя і здоров'я людини) та підтримання екологічної рівноваги, стимулювання розвитку екоорієнтованих технологій тощо на усіх етапах здійснення закупівель товарів, робіт і послуг (з моменту планування закупівлі до укладення й 
виконання договору про закупівлю) для забезпечення потреб держави, територіальних громад та об’єднаних територіальних громад.

Деталізація ж конкретних дій, заходів та напрямів діяльності в контексті здійснення екологічної політики України у сфері публічних закупівель потребує подальшого наукового осмислення та відповідного нормативно-правового закріплення з урахуванням обраного державою європейського вектору свого розвитку.

\section{Джерела та література}

1. Про Основні засади (стратегію) державної екологічної політики України на період до 2030 року: Закон України від 28.02.2019 р. № 2697-VIII // Відом. Верхов. Ради України. - 2019. - № 16. - Ст. 70.

2. Про публічні закупівлі: Закон України від 25.12.2015 p. № 922-VIII. [Електронний ресурс]. - Режим доступу: https://zakon.rada.gov.ua/laws/show/922-19.

3. Про внесення змін до Закону України «Про публічні закупівлі» та деяких інших законодавчих актів України щодо вдосконалення публічних закупівель: Закон України від 19.09.2019 р. № 114-IX. [Електронний ресурс]. - Режим доступу:https://zakon.rada.gov.ua/laws/show/114-20.

4. Краснова М. Правові основи сучасної екологічної політики України: науково-методологічні питання // Вісник Київського національного університету імені Тараса Шевченка. - Юридичні науки. - 2016. - № 1(102). -C. 9-13.

5. Про охорону навколишнього природного середовища: Закон України від 25.06.1991 p. № 1264-XII. [Електронний ресурс]. - Режим доступу: https://zakon.rada.gov.ua/laws/show/1264-12.

6. Про засади внутрішньої і зовнішньої політики: Закон України від 01.07.2010 p. № 2411-VI. [Електронний ресурс]. - Режим доступу:https://zakon.rada.gov.ua/laws/show/2411-17.

7. Екологічне право України в запитаннях та відповідях: навч. посіб. / А. П. Гетьман, М. В. Шульга, Г. В. Анісімова та ін. - Х.: Одіссей, 2008. - 480 с.

8. Заржицький О. С. Актуальні проблеми правового забезпечення екологічної політики України (теоретичні аспекти): моногр. / О. С. Заржицький. - Д.: Національний гірничий університет, 2012. $200 \mathrm{c}$.

9. Гетьман А. П. Правові засади державної екологічної політики в сфері охорони довкілля / А. П. Гетьман // Досвід i проблеми інкорпорації, імплементації та адаптації екологічного законодавства: матеріали міжнар. наук.-практ. конф., 25 верес. 2013 р., м. Дніпропетровськ / Ред. кол. B.I. Андрейцев [та ін.]. - Д.: Національний гірничий університет, 2013. - С. 53-71.

10. Угода про асоціацію між Україною, з однієї сторони, та Європейським Союзом, Свропейським співтовариством з атомної енергії і їхніми державами-членами, з іншої сторони: Угода від 27.06.2014 p. [Електронний ресурс]. - Режим доступу: https://zakon.rada.gov.ua/laws/show/984_011.

11. Про ратифікацію Угоди про асоціацію між Україною, з однієї сторони, та Європейським Союзом, Європейським співтовариством з атомної енергії і їхніми державами-членами, з іншої сторони: Закон України від 16.09.2014 p. № 1678-VII // Відом. Верхов. Ради України. - 2014. - № 40. - Ст. 2021.

12. Директива 2014/24/ЄС Свропейського парламенту і Ради ЄС від 26 лютого 2014 року про державні закупівлі та скасування Директиви 2004/18/ЕС. Збірник Директив СС з питань державних закупівель. 2015. [Електронний ресурс]. - Режим доступу: https://eupublicprocurement.org.ua/wpcontent/uploads/2015/02/EU-PP-Directives-Compendium_UKR.pdf.

13. Про Основні засади (стратегію) державної екологічної політики України на період до 2020 року: Закон України від 21.12.2010 р. № 2818-VI (втратив чинність) [Електронний ресурс]. - Режим доступу: https://zakon.rada.gov.ua/laws/show/2818-17.

Шевчук Л. Экологическая политика государства в сфере публичных закупок: подходы ЕС и законодательство Украины. Исследованы теоретико-правовые основы экологической политики Украины в сфере публичных закупок в условиях европейской интеграции государства. Проанализированы экологические стандарты ЕС и их закрепление в национальном законодательстве. Отмечено, что введение Законом № 114-IX норм экологического характера является результатом последовательного приближения законодательства Украины к acquis EC в сфере закупок в соответствии с Соглашением об ассоциации. Обоснован вывод о том, что усиление экологической составляющей в национальном законодательстве характеризует современную политику Украины, ориентированную на стандарты ЕС в сфере закупок в соответствии с Директивой 2014/24/ЕС. Отмечено, что отдельные нормы экологического характера, предусмотренные указанной Директивой 2014/24/EC, пока не нашли должного закрепления в национальной нормативно-правовой базе в сфере 
закупок. На основе анализа новелл законодательного регулирования экологических аспектов закупочной деятельности, а также исследования ведущих ученых-экологов сформулировано авторское определение понятия современной экологической политики Украины в сфере публичных закупок. Современная экологическая политика Украины в сфере публичных закупок является комплексной системой действий, мероприятий и направлений деятельности государства с участием общества, направленных на достижение целей устойчивого развития путем рационализации прямого и косвенного воздействия человека и результатов его деятельности на окружающую среду, снижение уровня загрязнения окружающей природной среды, достижения гармоничного взаимодействия общества и природы, охраны и оздоровления окружающей среды, сбалансированного использования природных ресурсов, обеспечения экологической безопасности (в том числе безопасности жизни и здоровья человека) и поддержание экологического равновесия, стимулирования развития екоориентованих технологий и т.д. на всех этапах осуществления закупок товаров, работ и услуг (с момента планирования закупки до заключения и выполнения договора о закупке) для обеспечения потребностей государства, территориальных общин и объединенных территориальных общин.

Ключевые слова: экологическая политика, публичные закупки, осуществления публичных закупок, закупка товаров, работ и услуг, Европейский Союз.

Shevchuk L. Environmental Policy of the State in the Public Procurement Sphere: EU Approaches and Legislation of Ukraine. The article highlights the theoretical and legal principles of the environmental policy of Ukraine in the field of public procurement in the context of European integration. In the focus of the study are the EU environmental standards and their enshrinement in national legislation. The author states that the introduction of environmental norms by Law No114-IX is the result of consistent approximation of the Ukrainian legislation to the EU acquis in the field of procurement in accordance with the Association Agreement. The author argues that strengthening of the environmental component in the national procurement legislation characterizes the current policy of Ukraine, focused on EU standards in the field of procurement in terms of Directive 2014/24/EU. But some environmental legislative regulations, provided for in the Directive 2014/24/EU, have not yet been properly incorporated in the national legalnormative documents on procurement. The author suggests his own definition of the concept of modern environmental policy of Ukraine in the public procurement sphere. Substantiation of the concept is based on the in-depth analysis of the legislative regulation novelties concerning ecological aspects of the procurement and findings of the researchers on the environmental issues. Modern environmental policy of Ukraine in the field of public procurement is a comprehensive system of actions, measures and activities of the state with the participation of society, aimed at achieving sustainable development goals by rationalizing direct and indirect human impact and results of its activities on the environment, reducing environmental pollution, achieving harmonious interaction of society and nature, protection and improvement of the environment, balanced using of natural resources, ensuring environmental safety (including safety of life and human health) maintaining ecological balance, stimulating the development of eco-oriented technologies, etc. at all stages of procurement of goods, works and services (from procurement planning to the conclusion and implementation of the procurement contract) to meet the needs of the state, local communities and united territorial communities.

Key words: environmental policy, public procurement, public procurement procedure, procurement of goods, works and services, European Union. 